\title{
Stereotypes about black bodies in French medical literature: race, gender and sexuality (I780-|950)
}

\begin{abstract}
This research focuses on the descriptions of African people's body according to French Doctors writings from the end of the 18 th century to mid-20th century. Though the black race is seen as monolithic group in the medical writings at the beginning of the period, the African multiplicity slightly came up under the colonial doctors' pens. Their action and their work started developing in the last third of the 19th century in parallel with the colonization. Beyond the principal human races classification, the French doctors and scientists established a hierarchy between the black peoples of Sub-Saharan Africa, from The Cape of Good Hope to Senegambia. The view on African bodies varied and became more refined all along the studied period, despite the permanency of numerous racial stereotypes. A sexual description of the peoples is added to the racial and ethnic taxonomy. Based on medical dictionaries, research monographs about human races or even on colonial medicine work, our work displays, within the descriptions of the black bodies, the overlapping of the theories about race, gender and kind, and also explains the similarity of the rhetorical methods used to define and describe the Other, should they be female or black. Moreover, this research highlights the way these representations thrived on scientific controversies, political concerns and interactions between home country practitioner medicine and colonial medicine on the field. Though the medical speeches stigmatize racial inferiorities or even the inversion of gender of the African people, this work also underlines the antithetical opinions and the conflicts between some doctors about these consensual patterns.
\end{abstract}

Keywords: colonization, sexuality, black bodies, hyper sexuality, Africans
Volume 3 Issue 3 - 2018

\section{Delphine Peiretti Courtis \\ Department of Archeology, France}

Correspondence: Delphine Peiretti Courtis, Department of Archeology, France, Email delphine.peiretticourtis@gmail.com

Received: November 28, 20I7| Published: May 21, 2018

\section{Introduction}

Hyper sexuality was one of the most common prejudices about Africans in the medical literature and, too, in popular depictions during the 19th century and at the start of the 20th. Given their supposedly overdeveloped sexes, black men and women in sub-Saharan Africa were thought to be predisposed by nature and by culture to have an immoderate, uncontrollable sexuality that justified, in particular, female circumcision and polygamy. The interest shown by doctors in the natives' sexuality was scientific, in the context of the emergence of sexology. Their intent was to learn about the sexuality of others in order to define sexuality in their own society by race, gender or class. They were also motivated by practical reasons, namely to understand the natives' sexual practices so as to control and preserve the sexuality of colonists. In effect, white expatriates who passed several months in the colonies underwent all sorts of temptations owing to the visible bodies of women, the so-called "free" sexuality and the climate - temptations to avoid for the sake of preserving the colonial power's integrity and authority. Out of these fears arose discourses and warnings about racial mixing and its dangers for the white race. Medical observations, descriptions and theories about a "black sexuality" (reified like "white sexuality") were intended to maintain racial boundaries and support colonialism. Black Africans' irrepressible sexuality was an argument for colonization and its "civilizing mission". The colonial power had to be the vector of moral values, including a moderate or hygienic sexuality.

The relationship between race, sex and gender about black people was made during this period

Sex and sexuality seem to "make" race in Africa. Hypersexuality, a common misconception about black peoples in the colonial era, was built on the idea that skull shape, brain weight and the size of the genitals would reveal in the Negroes a predisposition to carnal instincts and pleasures but also an intellectual weakness. "It is still the same way that, with the Negro, the intellectual organs being less developed, the genitals acquire more preponderance and extension" can we read in the Gazette Medicine of Paris in 1841. The cerebral zones intended for the emotion and sensations would be overdeveloped in African brains which would explain the exacerbated development of their sexual attributes and sexuality. If the hypotheses on cerebral localizations and their links with race sexuality gradually disappear in the first decades of the twentieth century, it is necessary to wait until the 1940s for colonial doctors like Lefrou to question the conventional wisdom about organ overdevelopment. ${ }^{1,2}$

\section{Genitals in the blacks}

Beyond the sex and sexuality that would imprint their mark on the bodies and culture of Africans, the genre would seem troubled in Africa. In medical descriptions of the nineteenth century and the first half of the twentieth century, gender inversion and that of sexual differences seem to characterize the African peoples. Women are portrayed as virile because of the hard work they do, their muscular bodies, their short hair, the courage and endurance they show, while the men are portrayed as effeminate because of their laziness, their intellectual inferiority, their inconstancy or their hairless body, like women and children. The undifferentiating of the gender in Africa, considered as an essential character of civilization, is also one of the arguments presented by doctors to advocate the benefits of a civilizing mission. This would have the purpose of policing morals and sexuality but also to redefine the social roles specific to each gender 
in African societies. Discourse surviving black men for their physical strength and robustness also existed in medical books throughout the period studied and particularly at the turn of the nineteenth and twentieth century's when the degeneration of the white race worries the medical and political sphere. The black body then becomes an example of virtue and resistance to offer to white men weakened by civilization and urbanization. African femininity is also valued during the nineteenth and first twentieth century when it comes to presenting a model of maternity to white women forsaking their mission. If Africans are erected, according to the political or social context in France, as an example for the French, everything seems nevertheless to bring them back to their body, presented as their main strength and wealth. These discourses have political consequences. Feminization but also the infantilization of black peoples led to a more general devaluation of Africans, which had political repercussions such as to justify the colonization of men considered inferior, intellectually or even physically close to women and children. And subject to their passions. Thus, the famous speech of Ferry in 1885 draws its roots in the breeding ground of the radiological medicine and in the tests brought by the scientists of an inferiority of the black race. Similarly, while the writings of colonial doctors have highlighted African diversity, they have generated, by aiming to rationalize the colonial work, a strengthening of ethnic groups but also differentiations and hierarchies still existing today in Africa.

Beyond the descriptions that helped to enhance some ethnic groups rather than others in a colonial logic, the medical discourses gave rise to practical applications. The invention of a robustness index specific to the black race in the 1930s has allowed civil and military doctors to measure the degree of resistance and physical strength of men. The enlistment of the "black force", mentioned by General Mangin in the 1910s, or the recruitment of labor for the construction of infrastructures such as the Congo-Océan railway, with deadly effects, have made using theories, methods and tools that physicians have Finally, the need to "make black" for the minister of the colonies Albert Sarraut in 1923 or for the doctor Gustave Lefrou doctor-commander of the Department of health of the A.O.F, in 1943, took concrete form in the field through the establishment of public health programs, vaccination campaigns, but also reports and missions for the protection of motherhood and childhood. The medical knowledge of the black peoples was intended to deepen the anthropological knowledge of the races of humanity, to unravel the scientific controversies between monogenists and polygenists but also to set up a preventive medicine for settlers and colonized to ensure the success of the colonial work. ${ }^{2,3}$

Within the taxonomic movement initiated by the naturalists Linné, Buffon or Blumenbach and an order of humanity in races in the second half of the eighteenth century is shaping a dense and phantasmagorical imagination around the black people to mid-twentieth century. From the pigmentation of the epidermis and cranial morphology to the dimensions of their muscles or the shape of their sexual attributes, the bodies of black men and women in sub-Saharan Africa fascinate
French scientists. With the aid of a methodological arsenal that is being put in place and perfected throughout the nineteenth century, the black people is studied as a monolithic category with essentialized physical and moral characteristics. However, the gaze on the black populations evolves from the years 1870-1880. By approaching its object of study, the colonial doctor provides a multitude of writings, descriptions, measurements and photographs of the African peoples, which nourish the radiological analyzes of the doctors in France. They make emerge the conscience of the existence of intra-population diversity in Africa. However, stereotypes about black people such as intellectual inferiority, physical strength and laziness, hypertrophy of sexual attributes or hypersexuality are divided among ethnic groups. This redistribution, as well as the increasing consideration of cultural and individual differences in the first half of the twentieth century, nevertheless contributes to weakening and enhancing racial and sexual stereotypes about black bodies.

\section{Conclusion}

The progress of genetics since the early twentieth century and the misuse of medical sciences during the Holocaust lead to the invalidation and condemnation of the concept of race by a group of scientists gathered under the auspices of UNESCO in the 1950s. To this postwar context is added the fall of colonial empires in the 1960s, which led to a disavowal of radiology and its practices. Culture becomes the prism of study of African populations despite the permanence and regular resurgence of a number of representations on black bodies to the present day as the idea of natural force or irrepressible sexuality, showing the strength of representations constructed and validated by science in the nineteenth century. ${ }^{4,5}$

\section{Acknowledgements}

None.

\section{Conflict of interest}

Author declares that there is no conflict of interest.

\section{References}

1. Blanckaert C. La Vénus Hottentote entre Barnum et Muséum. Paris: Publication du Muséum national d'histoire naturelle; 2013.

2. William BC. Français et Africains, les Noirs dans le regard des Blancs 1530-1880. Paris: Gallimard; 1981

3. Dorlin E. La matrice de la race. Généalogie sexuelle et coloniale de la nation française. Paris: Editions La Découverte; 2006.

4. McClintock. Imperial Leather: race, gender and sexuality in the colonial contest. New-York: Routledge; 1995.

5. Reynaud P. La République raciale. Paradigme racial et idéologie républicaine (1860-1930). Paris: PUF; 2006.

6. Stoler AL. La chair de l'empire. Savoirs intimes et pouvoirs raciaux en régime colonial. Paris: La Découverte; 2013. 